\title{
Emerging trends in power electronics, electric drives, power and energy storage systems
}

\author{
Michal Frivaldský ${ }^{1}$
}

Published online: 5 March 2020

(c) Springer-Verlag GmbH Germany, part of Springer Nature 2020

This special issue of Electrical Engineering-Archiv fur Elektrotechnik is oriented on the emerging trends of electrical engineering with particular reference to power electronics, power electrical systems, energy storage systems, electrical drives and machines. The papers are extended versions of contributions presented at the ELEKTRO 2018 conference held from 21 to 23 May 2018 in Mikulov, Czech Republic, with more than 120 conference participants and over 100 scientific contributions focusing on a broad spectrum of topics: power electrical systems, control and information systems in transport industry, materials and technologies for electrical engineering, power electronics, robotics and cybernetics, mechatronics, trends in theoretical, applied electrical and biomedical engineering, education in electrical engineering and information and communication technology.

The papers collected in this special issue show that current trends are defined by the rise of studies in the field of e-mobility. In particular, the use of technologies of wide- band gap devices allowing to use converters with extreme power density and efficiency is documented and recent experiences non-conventional design of electric drives and their control are presented. Hybridization is another important topic. Some papers present novel battery technologies and improved battery management systems controls that enable the development of new automotive and energy systems. Topics related to reliability, safety, thermal management systems and performance are also dealt with in this special issue.

Let us thank the authors, colleagues, reviewers and those who contributed and prepared this issue of the journal of Electrical Engineering-Archiv fur Elektrotechnik.

On behalf of the organizing and scientific committee of the ELEKTRO 2018 conference.

Michal Frivaldský

Publisher's Note Springer Nature remains neutral with regard to jurisdictional claims in published maps and institutional affiliations.
Michal Frivaldský

michal.frivaldsky@fel.uniza.sk

1 Zilina, Slovakia 